\title{
Prospects of a Christian Ethics of responsibility (Part 1): An assessment of an American version
}

D E de Villiers

(University of Pretoria)

\section{ABSTRACT}

Prospects of a Christian Ethics of responsibility (Part 1): An assessment of an American version

In his book Das Prinzip Verantwortung, published in 1979, the philosopher Hans Jonas argued that all existing approaches in philosophical ethics are inadequate, because they do not effectively address the serious issues caused by the rapid expansion of modern technology. He proposed a completely new approach to ethics based on the principle of responsibility. His book - among others inspired a number of theologians in Germany and the USA to develop their own versions of a Christian ethics of responsibility. In this article Jonas's version of an ethics of responsibility and the attempt of the American theologian William Schweiker to develop a Christian version of such an ethics in close proximity to Jonas's are critically discussed. It is pointed out that Jonas does not succeed in making out a convincing case for elevating responsibility to the fundamental principal of ethics. It is also argued that Schweiker's ambivalent stance in this regard does not support his claim that Christian ethics, in order to adequately respond to the serious ethical issues of our time, should be developed as an ethics of responsibility. The question "Can and should Christian ethics today be developed as ethics of responsibility?" is therefore left open.

\section{INTRODUCTION}

In his now famous book After virtue: A study in moral theory, published in 1981, the philosopher Alasdair MacIntyre verbalised a growing feeling at the time that modern ethics was inadequate. As alternative he proposed an updated version of the virtue ethics that dominated Western philosophy for the greatest part of two millennia since Aristotle. Many Christian ethicists, not only in Roman Catholic, but also in Protestant circles, have accepted MacIntyre's proposal for an alternative ethical approach. In fact, it is the Protestant Stanley Hauerwas who has most effectively promoted a Christian version of virtue ethics, or - as he prefers to call it - an ethics of character (see e.g. Hauerwas 1975). As a result of his and 
other proponents' efforts there is today widespread agreement among Christian ethicists that Christian Ethics can only be regarded as adequate if it is, at least partly, practised as virtue ethics.

MacIntyre's proposal was not the only proposal for a new and more adequate approach in ethics made during the latter part of the twentieth century. Two years before the publication of After virtue the philosopher Hans Jonas's book Das Prinzip Verantwortung: Versuch einer Ethik für die technologische Zivilisation was published in Germany. In his book Jonas also strongly argued that current approaches to ethics were inadequate (Jonas 1984a:6 and 8) ${ }^{1}$. Jonas set himself the task in his book to develop such a completely new ethical approach based on the principle of responsibility, understood by him as the prospective and unilateral responsibility to ensure the continuing existence of humankind.

Jonas's book was quite influential, especially in Germany, in stirring a lively public debate on the risks of technological development and the ethics needed to counter these risks effectively. A number of German theologians did not only become involved in the public debate on Jonas's proposal for an ethics of responsibility, but also ventured to develop Christian versions of such an ethics. Wolfgang Huber was the first Protestant theologian to do so, but he was soon followed by younger theologians like Johannes Fischer, Hartmut Kress, Wolfgang Erich Müller and Ulrich Körtner. Josef Römelt is a Roman Catholic theologian who worked out a "Theology of Responsibility" in dialogue with Jonas' ethics. In the USA William Schweiker has since the nineties developed his own version of a Christian ethics of responsibility ${ }^{2}$.

There is something very attractive and - at first glance - also convincing about the proposal to conceive Christian ethics in our day as an ethics of responsibility. One can hardly deny that today all ethics has to deal with the phenomenon of the enormous increase in, but also severe lack of, moral responsibility that accompanies the expansion of human power as a result of technological development.

1 References in this article are to the English translation of Jonas's book: The imperative of responsibility: In search of an ethics for the technological age, published in 1984.

2 For the publications in which these theologians developed their views on a Christian ethics of responsibility, see the Consulted literature 
Apart from this the concept of responsibility resonates far more positively with the contemporary mindset than the concept of duty, and has almost completely substituted it. The concept of duty smacks to us of authoritarianism, while the concept of responsibility has associations with those of autonomy and personal initiative, which are valued positively in our time. In a recent publication Winston Davis even asserts that responsibility has become the queen of the modern virtues. He is of the opinion that it became the dominant public virtue in the USA during the second half of the twentieth century (Davis 2001:xi and 1) ${ }^{3}$.

Despite the promise that the responsibility ethics approach in Christian ethics apparently holds, one unfortunately has to conclude that this promise has - up to date - not been fulfilled. It has not been nearly as successful as the virtue ethics approach in attracting supporters among Christian ethicists, clergy and church members. A major reason is that the proponents of a Christian ethics of responsibility have not succeeded in establishing it as a distinctive alternative approach in Christian ethics. The problem is that their views are quite disparate, mainly because they do not seem to share a common definition of "ethics of responsibility". To put it another way: the views put forward by proponents as Christian ethics of responsibility do not exhibit enough of a family resemblance to justify talk of a responsibility ethics school in Christian ethics.

Why is this the case? In my opinion it has much to do with the fact that the Christian proponents of an ethics of responsibility differ sharply in their appraisal of Hans Jonas's attempt to develop a radically new ethics. What is of special importance is that they respond differently to his depiction of the defining features of an ethics of responsibility and his view that a universal, metaphysical and realistic foundation for such an ethics is needed. Although William Schweiker criticises some of Jonas's views and makes some necessary adaptations, he tries to stick as close as possible to the overall structure of Jonas's ethics. As in Jonas's ethics, an imperative of responsibility is also the centrepiece of his Christian version of an ethics of responsibility. He shares Jonas's conviction that a universal, realistic foundation for an ethics of responsibility is needed. The

3 For distinctively contemporary associations of the term 'responsibility' see also McKeon (1957:6-7) and Mitcham (1987:27). 
other proponents reject both Jonas's definition and realistic foundation for an ethics of responsibility. They develop their own and disparate views of what a Christian ethics of responsibility comprises and do not endeavour to provide a universal foundation for their ethics.

I am also not convinced by Jonas's view of what an ethics of responsibility comprises. Neither do I think that a Christian ethics of responsibility needs a universal, realistic foundation. In this article I want to demonstrate why the attempt to develop a Christian ethics of responsibility in close proximity to Jonas's ethics is problematic. I start with the description of Jonas's and Schweiker's views and then proceed to a comparison and an evaluation of their views. In conclusion the pivotal question is addressed: what are the prospects for the development of responsibility ethics as an alternative approach in Christian ethics if one has to conclude that it cannot be based on Jonas's conception?

\section{HANS JONAS AND WILLIAM SCHWEIKER: THE CENTRALITY OF THE IMPERATIVE OF RESPONSIBILITY}

Jonas is convinced that ethics, as practised in the past, is not able to deal with the moral problems involved with modern technology, because its focus was only on the short-term consequences of human actions (Jonas 1984:5) ${ }^{4}$. What we therefore urgently need, in his opinion, is a completely new ethics that does not only recognise the enormous expansion of human responsibility in correlation with the enormous expansion of human power as a result of technological development, but also provides an adequate foundation for the moral responsibility to ensure the future existence of humankind. The basic imperative of such an ethics of responsibility or ethics of the future is: "Act so that the effects of your action are compatible with the permanence of genuine human life"; or expressed negatively: "Act so that the effects of your action are not destructive of the future possibility of such life” (Jonas 1984:11).

4 Jonas developed his ethics of responsibility in Das Prinzip Verantwortung: Versuch einer Ethik für die technologische Zivilisation (1979) and applied it in Technik, Medizin und Ethik: Zur Praxis des Prinzips Verantwortung (1985) to particular ethical issues in technology and medicine. See Böhler (1994:460-476) for a bibliography of Jonas's own publications and publications on Jonas. 
In seeking a foundation for such a new ethics Jonas makes use of what he calls a "heuristic of fear". The "heuristic of fear" does not share the optimistic assumption of Ernst Bloch's "heuristic of hope" that the solution to problems caused by modern technology can be found in the ever more effective use of technology itself, but gives priority to apprehension over optimism when the future consequences of the application of technology are uncertain, and to restraint over activism in the use of technology in such cases (Jonas 1984:26-27, 202-203).

Jonas believes that the "heuristic of fear" can help us to find out what it is about humankind that needs to be preserved. What foundation can, however, be given to the duty or responsibility to preserve humankind in future? Normally, the rationale for a particular duty or responsibility can be provided by demonstrating that a particular right that corresponds to it, exists. Only those who already exist can, however, claim to have certain rights. That is obviously not the case with future generations. Jonas tries to solve the problem by asserting that the present generation is not so much responsible for humans, living in future, than for the embodiment of the idea of humankind. The first imperative of Jonas's ethics is therefore: there ought to be humankind (Jonas 1984:43).

Jonas is convinced that the sense of awe for the sacred provided by religion in the past cannot provide a firm foundation for the obligation to ensure the future embodiment of the idea of humankind anymore, because the Enlightenment has resulted in the eclipse of religion (Jonas 1984; cf also Jonas 1987:1-13). He therefore seeks to find the foundation in the teleological structure of nature. The "purposiveness" (i.e. the mere capacity to have purposes) imbedded in nature is, in his opinion, to be regarded as a "good-in-itself" that entails the obligation to ensure its future existence (Jonas 1984:78-80).

To the foundation of this "objective" imperative Jonas adds a foundation of the "subjective" second imperative of responsibility that is needed to provide the necessary motivation to preserve humankind in future. The foundation for this non-reciprocal responsibility is provided, in his opinion, in the paradigms of the non-reciprocal responsibility of the parent and the statesman. They are motivated by a one-sided responsibility - that is total, continuous and future-orientated in nature - to ensure the existence and welfare 
of other people. In the same way the present generation can and should be motivated by a one-sided responsibility for the existence and welfare of future generations (Jonas 1984:98-108).

In an effort to develop what he calls "an integrated theory of responsibility" William Schweiker draws insights from various theories of responsibility (Schweiker 1995:32) ${ }^{5}$. He groups all previous theories of moral responsibility into three types: agential, social and dialogical. He calls an ethics in which responsibility serves as first principle "strong" as opposed to a "weak" ethical paradigm that deals with the idea of responsibility, but does not regard it as the first principle of ethics. "Ethics of responsibility can be classified, then, in terms of moral focus (agential, social, dialogical) and with respect to the first principle of an ethics (strong, weak)" (Schweiker 1995: 42-43).

The imperative of responsibility that forms the centrepiece of Schweiker's theological ethics of responsibility is formulated by him as such: "in all actions and relations we are to respect and enhance the integrity of life before God" (Schweiker 1995:2). He denies, however, that by depicting this imperative as "imperative of responsibility" he is elevating responsibility to the first principle of ethics, as it was done in the theological ethics of responsibility of $\mathrm{H}$ Richard Niebuhr and Bernhard Häring, based on strong dialogical theories of responsibility. Responsibility does not specify the moral good for the ethics he proposes. Rather, "(m)oral integrity is the substantive moral good and hence focus in theological ethics; the idea of responsibility provides the means for thinking about the meaning of that good for how we ought to live. Neither a "strong",

5 Schweiker developed his view on a theological ethics of responsibility in his books: Responsibility and Christian Ethics (1995) and: Power, value and conviction: Theological ethics in the postmodern age (1998). See also: Radical interpretation and moral responsibility: A proposal for theological ethics, The Journal of Religion 73(40): 613-637 from 1993; "Verantwortungsethik in einer pluralistischen Welt: Schöpfung und die Integrität des Lebens”, Evangelische Theologie 59(5): 320-335 from 1999, and: "Responsibility in the world of Mammon: Theology, justice and transnational corporations”, in: Stackhouse, M L \& Paris, P J (eds), God and globalization. Volume 1: Religion and the powers of the common life (2000), 105-139. In his Theological ethics and global dynamics in the time of many worlds (2004) the basic structure of his view on a Christian ethics of responsibility developed in earlier publications is maintained (cf 2004:xiv). 
nor "weak" theory of responsibility, the position of this book is what I have called an integral theory of responsibility" (Schweiker 1995:44).

By including in his formulation of the imperative of responsibility the qualification, "before God," Schweiker wants to make it clear that he is proposing a thoroughly theological ethics of responsibility. He is not only asserting that the norms of responsibility and the moral worth of others and ourselves are defined in relation to the divine and not solely by more proximate relations and communities. He is also attempting to demonstrate that a theological account of responsible moral existence makes better sense of our intuitions about responsibility than important philosophical positions have done. Or to put it in his own words: "My contention is that once we properly understand what is meant in Christian faith by the symbol 'God', it is required, or at least a functional equivalent to it is required, for an adequate ethics of responsibility” (Schweiker 1998:94).

Although Schweiker depicts himself as a proponent of moral realism, he does not subscribe to classical moral realism that holds that there is an intelligible moral order written into nature and the human mind. He rather subscribes to what he calls "hermeneutical realism" that holds that narratives and metaphors shape but do not determine perception (Schweiker 1998:10-11) ${ }^{6}$. It is his contention that the symbol of "God," the ultimate power, as it has been given shape in the Christian tradition, provides an adequate basis for the imperative of responsibility. It is because the name "God" symbolises the transformation of power with respect to recognition of and regard for finite goodness and derivative claims of justice and benevolence. The interpretation of the symbol "God" within moral inquiry enables one to attain an insight into the worth of reality and others, an insight that also determines moral identity (Schweiker 1998:107-108).

6 Schweiker (1998:82-86) distinguishes his "hermeneutical realism” from other forms of moral realism in theology: divine command ethics (i.e. Karl Barth), natural law ethics (i.e. Thomas Aquinas), internal realism (i.e. Stanley Hauerwas), self-transcending realism (i.e. Paul Tillich) and critical realism (i.e. Gordon Kaufman and Sally McFague). 


\section{COMPARISON AND EVALUATION}

A comparison of Jonas's and Schweiker's views clearly shows the resemblances, but also differences, between their views. Both of them are of the opinion that the idea of responsibility (for the survival of future life on earth) should take centre stage in contemporary ethics as a result of the risks involved with the radical extension of human power through rapid technological development. Jonas, however, is more radical than Schweiker in this regard. For him responsibility for the survival of future life on earth is not only one of the central problems contemporary ethics faces - a conviction shared by Schweiker - but the overriding and urgent problem that makes it necessary to at least temporarily shelve other traditional concerns of ethics ${ }^{7}$. Schweiker clearly shies away from this onesided conceptualisation of the ethics of responsibility as a "future ethics" concerned with only the future survival of life on earth ${ }^{8}$. Both Jonas and Schweiker find the fact that no universal basis for ethics is recognised today highly problematic. Jonas, however, sees the main reason for this in the demise of religion as foundation for ethics in the modern world. Schweiker is of the opinion that pluralism is rather to be blamed. The centrepiece of both Jonas's and Schweiker's versions of the new ethics of responsibility is an imperative of responsibility. In the case of Jonas the imperative of responsibility relates exclusively to the survival of humankind, while Schweiker's imperative of responsibility includes the enhancement of the integrity of all life on earth. Like Jonas, Schweiker defends moral realism, which "holds that there is actually one true moral order,"

7 "If... the conditions of existence are jeopardized, then it could be that for a while the higher aspirations for perfection, for the best life, indeed even for the "good will" (Kant) must step back in ethics behind the more vulgar duties which our equally vulgar causality in the world lays upon us... For the time being, the horizontal dynamics we have unleashed ourselves "has" us by the scruffs of our necks. Even the suspicion that what I called the abolition of transcendence may have been the most colossal mistake in history, does not relieve us of the fact that, now and until further notice, responsibility for what has been set afoot and is kept moving by ourselves, takes precedence before everything else" (Jonas 1984:128-129).

8 In Theological ethics and global dynamics in the time of many worlds (2004), for example, Schweiker spends a chapter on the discussion of present day demands of responsibility with regard to the high level of violent conflict and the legacy of many forms of suffering in the world (2004:110-127). 
over against the anti-realist sentiment of our time (Schweiker 1998:27). The important difference is that Schweiker, in contrast to Jonas, maintains that only theology can provide a firm basis for such an ethics.

An evaluation of Jonas's and Schweiker's views has to start with the pivotal question: do they make out a convincing case that the new ethics needed in our time and developed by them has to be an ethics of responsibility? By depicting the new ethics as such they clearly imply that "responsibility" is its defining feature.

Jonas provides two reasons for depicting the new ethics that is - in his opinion - needed in our time as ethics of responsibility. The first is that the problem of responsibility for the survival of humankind in future is the central problem of contemporary ethics. By doing this Jonas does not only demonstrate in what sense the concept of responsibility stamps his ethics in an important way, but also suggests that ethics can in our day only be regarded as adequate if it is transformed into future ethics. The second reason - according to Jonas - is that the imperative of responsibility is the fundamental normative principle of his contemporary ethics devoted to the future survival of humankind. By doing this he demonstrates in yet another way the contemporary centrality of the concept of responsibility in ethics and the reason for depicting this ethics as ethics of responsibility.

One can fully understand the hesitation of Schweiker to define Christian ethics in terms of a single contemporary problem with regard to responsibility, and to reduce it accordingly to future ethics. To do so would mean to ignore other serious moral issues and to screen out the time dimensions of the present and the past in Christian ethics. By not following Jonas in this regard, however, he also abandons one clear way of demonstrating how the concept of responsibility qualifies contemporary ethics.

The main reason for Jonas's depiction of the new ethics he propagates as an "ethics of responsibility" is that it is based on a "substantive, goal-committed concept of responsibility" (Jonas 1984:93). The crucial question is whether responsibility can ever serve as the substantive normative principle of a particular normative ethical theory. As, inter alia, the philosopher Kurt Bayertz has pointed out in criticism of Jonas's attempt to do just that, responsibility is a second level normative concept, which cannot 
function as a substantive normative principle on the first level (Bayertz 1995:65-66).

The function of the concept of responsibility is to establish a particular relationship between moral agents and outcomes. Such a relationship is established if the outcome is rightly ascribed to the agent or agents, irrespective of whether this outcome is the result of past actions (retrospective ascription), or rather a particular state of affairs that should be preserved or attained in the present and in future (prospective ascription). The task of a theory of responsibility is, accordingly, to develop and found criteria for such ascription. According to the classical theory of (retrospective) responsibility, for example, someone is guilty if it can be established that a negative outcome is causally linked to the actions and intentions of that person, and his/her actions and intentions contradict the values of the particular society (Bayertz 1995:14-15). In different contexts the criteria for ascribing an outcome to an agent can differ. In all cases, however, the ascription of responsibility presupposes evaluation. It is important to take into account that this evaluation takes place independently of the ascription of responsibility. It is one thing to ask whether a particular result of actions ought to be evaluated as bad, but quite another to ask to whom it ought to be ascribed (retrospective responsibility). Likewise, it is one thing to ask which state of affairs ought to be evaluated positively and ought, as a result, to be preserved or attained, and quite another to ask to whom the task to do that ought to be ascribed (prospective responsibility). According to origin, content and goal these evaluations lead to different types of responsibility, for example: moral, legal or functional responsibility. The concept of responsibility does not, however, constitute any evaluations, but only "transports" it; it is value neutral. For that reason one can say that the theory of moral responsibility feeds on the theory of morality: it lives off moral evaluations that it cannot ground itself (Bayertz 1995:65-67) ${ }^{9}$.

9 Compare also the conclusion W Wieland comes to after a critical discussion of Hans Jonas's attempt to ground the new future ethics he proposes in the imperative of responsibility: "Im Gegensatz zu seinem Selbstverständnis, im Gegensatz auch zur Auffassung der Mehrzahl derer, die seine Thesen rezipieren, ist Jonas ... weit davon entfernt, ein neues Prinzip der Ethik entdeckt zu haben. Sein "Prinzip Verantwortung” kann schwerlich den Status einer im strengen Sinne neuen ethischen Leitnorm in Anspruch nehmen. Mit 
By trying to base his proposed future ethics on a material principle of responsibility Jonas ignores the important meta-ethical insight that the theory of responsibility and the theory of morality do not coincide. He does not, however, prove this insight wrong. If one looks more closely, he does not really succeed in demonstrating that responsibility is the substantive normative principle of the future ethics he proposes. He introduces the one-sided responsibility of the parent for his or her child as model for the one-sided responsibility for the survival of future generations. By doing that he, to some extent, succeeds in explaining what he means by prospective responsibility for future generations, but he does not succeed in providing a convincing and universally acceptable foundation for it. First of all, although the feeling of parental responsibility may have its origin in natural instincts, its content is not universally uniform, but culturally determined. Or to put it another way: parental responsibility presupposes existing evaluations of what good parenting entails. For example, maternal responsibility does not in all cultures include the obligation for the mother to breastfeed her child. There are also cultural differences with regard to the required length of the breastfeeding period. Secondly - and more importantly - there is no way in which the prospective responsibility for the survival of future generations can be deduced from parental responsibility or from the responsibility of the statesman as such. The one-sided responsibility of both the parent and the statesman is limited in more than one respect. In both cases it refers to a circumscribed - and culturally determined - set of obligations to a circumscribed number of persons within a circumscribed timeframe. The prospective responsibility for future generations is unlimited with regard to the extent of obligations, the number of persons and the timeframe involved (cf Kettner 1990:424-426). Referring to existing examples of similarly one-sided, but distinctively limited and culturally determined, responsibility does not universally ground such an unlimited responsibility.

Hilfe dieser Formel wird in Wirklichkeit nur die Forderung erhoben, dass der Mensch die ihm als sittlicher Person schon von Hause aus zukommende Verantwortung, wie immer sie auch zu definieren und zu begründen ist, künftig auf einen räumlich wie zeitlich ungleich grösseren Einzugsbereich ausdehnen soll als bisher" (Wieland 1999:11-12). 
It comes as no surprise that Jonas does not content himself with the attempt to ground the imperative of responsibility in the responsibility of the parent and the statesman. He feels obliged to supplement his foundation of prospective responsibility as a "subjective" principle with an ontological or metaphysical foundation of the "objective" principle: "Act so that the effects of your action are compatible with the permanence of genuine human life" (Jonas 1984:11). He attempts to ground this principle in the teleological order of nature, more particularly in "purposiveness" itself as "good-in-itself" that implies the obligation to ensure its continuing embodiment in human beings in the world. In doing so Jonas in fact admits that prospective responsibility for the survival of future generations presupposes a substantive moral principle. To call this moral principle the imperative of responsibility is - to say the least - misleading. It would have been more apt for Jonas to call it "the fundamental moral principle of future ethics".

As we have seen, William Schweiker distinguishes between "weak" and "strong" forms of the ethics of responsibility. His depiction of all ethics that explicitly deals with the question of responsibility, without elevating responsibility to a fundamental ethical principle, as "weak" ethics of responsibility is not very convincing. The implication is that one can name a particular ethics with reference to any of the number of ethical issues it deals with. His reason for depicting "strong" ethics of responsibility as such is that it takes responsibility as its fundamental normative principle. The criticism expressed against Jonas's attempt to define the ethics of responsibility in terms of responsibility as substantive moral principle also applies to this depiction.

It is conspicuous that the same inconsistency is found in Schweiker's foundation of his ethics. In spite of making what he calls the "imperative of responsibility" - "in all actions and relations we are to respect and enhance the integrity of life before God" (Schweiker 1995:2) - the centrepiece of his own Christian ethics of responsibility, he has to deny that he elevates responsibility to a fundamental ethical principle. He rightly asserts that moral integrity is rather the substantive moral good from which his ethics takes its point of departure. As this is the case it is not clear why he calls the fundamental imperative of his ethics an "imperative of responsibility" in the first place. Used in this way, the phrase 
"imperative of responsibility" is in fact nothing more than a synonym for the phrase "fundamental ethical imperative".

In Responsibility and Christian ethics Schweiker, apart from developing his own Christian version of an "integrated theory of responsibility," also provides a number of illustrations of "strong" versions of the ethics of responsibility. Prominent proponents of such an ethics are, in his opinion, Immanuel Kant, Paul Tillich and $\mathrm{H}$ Richard Niebuhr (Schweiker 1995:79-85; 98-103). According to Schweiker, Kant and Tillich developed "strong" agential theories of responsibility. He admits that Kant does not use the term responsibility in his ethics, but asserts that it is fitting for us to consider Kant's moral philosophy as an ethics of responsibility, insofar as autonomy, and thus responsibility for self, is basic to his ethics (Schweiker 1995:79). Although Tillich does not provide any in-depth analysis of the concept of responsibility, Schweiker nonetheless argues that he presents a Christian agential theory of responsibility, because he holds the agent responsible for selfactualization under the law of essential human nature (Schweiker 1995:84). It seems strange that he has to resort to ethical theories in which the concept of responsibility does not play a central role to provide examples of a "strong" agential theory of responsibility. He attempts to give credence to his claim by arguing that autonomy (in the case of Kant) and theonomy (in the case of Tillich) implies responsibility for self or self-actualisation. That may be true, but it does not prove that responsibility is the fundamental moral principle of the ethics of either Kant or Tillich. The fundamental moral principle is in the case of Kant rather the "categorical imperative" in its different versions, and in the case of Tillich the "moral imperative is the command to become what one potentially is, a person within a community of persons” (Tillich 1963:19).

Schweiker's strongest case for the existence of a "strong" theory of responsibility seems to be H Richard Niebuhr's Christian ethics of responsibility. According to Schweiker, Niebuhr develops in his The responsible self a "strong" dialogical theory of responsibility in which responsibility figures as the first principle of ethics (Schweiker 1995:94, 98). Niebuhr contends that three fundamental images or symbols have dominated Western accounts of the human agent: "man-the-maker," "man-the-citizen" and "man-theanswerer" (Niebuhr 1978:47-57). To these three symbols correlate respectively three different understandings of ethics: teleological 
ethics, deontological ethics and responsibility ethics (Niebuhr 1978:57-61) . Niebuhr sets himself the task to explore the meaning of the new symbol of "man-the-answerer" associated with the equally new concept of responsibility. He isolates four elements of responsibility that constitutes one complex, moral description of life. Responsible action consists of (i) response to action upon us; (ii) response to interpreted actions; (iii) accountability, which means response in anticipation of responses to our actions and (iv) social solidarity, which means response to action upon us in a continuing discourse or interaction among beings forming a continuing community (Niebuhr 1978:61-68). The scope of the moral community Niebuhr has in mind is universal. This is because life is lived finally in response to the One God. The central claim of his ethics is therefore: "God is acting in all actions upon you. So respond to all actions upon you as to respond to his action" (Niebuhr 1978:126). As a result the leading question of the ethics of responsibility in every moment of decision and choice is: "What is going on?" On the basis of the answer to this question it proceeds to seek the fitting action, the one that fits into a total interaction as response and as anticipation of further response (Niebuhr 1978:61).

It is important to take into account that what Niebuhr is first of all developing in The responsible self, is a dialogical or relational Christian anthropology. In spelling out what humans are from a Christian perspective, he utilises the symbol of responsibility. He draws on the polysemy of the verb "to respond," from which the noun "responsibility" is derived, on both its senses of "to answer for" and "to respond to" 10 . The last sense receives more emphasis from Niebuhr than the first sense, which is more closely related to the founding concept of imputation for which the concept of responsibility has become the substitute in our time. One may rightly assert that Niebuhr is ascribing to the term "responsibility" a broader, if not a different, meaning than is usually the case when this term is used in philosophy and the legal and political sciences. The term "responsiveness" would probably be a more apt term than "responsibility" to describe what Niebuhr has in mind when he

10 For a semantic analysis or "conceptual semantics" (as he prefers to call it) of the concept of responsibility consult Paul Ricoeur's essay on: The concept of responsibility: An essay in semantic analysis, in his book The just (2000), 11-35. 
develops a Christian anthropology from the perspective of the symbol "man-the-answerer".

Apart from the question whether the concept of responsibility that plays a central role in Niebuhr's anthropology is the same one that is at stake in the ethics of Jonas and Schweiker, it would in any case be difficult to maintain that responsibility is the substantive principle in Niebuhr's ethics. It is true that Niebuhr, in discussing the ethical implications of the relational anthropology he develops, does not formulate a particular substantive moral principle from which other more specific moral obligations can be derived. What the morally right thing to do is can only be determined in the concrete situation. In the concrete situation it is, however, not so much responsibility or responsiveness as such that provides substantive moral guidance. It is rather insight into what God is doing in the situation, and deliberation on what the fitting response is to what $\mathrm{He}$ is doing, that provides this guidance.

The conclusion seems unavoidable that responsibility does not and cannot serve as the substantive moral principle of a particular normative ethical theory. It is therefore also not viable to define ethics of responsibility, including Christian ethics of responsibility, in terms of responsibility as substantive moral principle. Or to put it another way: the term "ethics of responsibility" cannot refer to a distinctive normative ethical theory.

Should one not nonetheless maintain with Jonas and Schweiker that prospective responsibility for the protection and enhancement of life on earth should today be a major theme in both philosophy and theology? And should one not agree with them that the effective exercise of such a responsibility would only be possible on the basis of a universal, realistic ethics? The answer to the first question can only be in the affirmative. Such an affirmation does not, however, mean that prospective responsibility issues should preoccupy ethicists to the extent that other urgent contemporary moral issues, including those regarding the ascription of retrospective responsibility, for example, in the case of war crimes, may be ignored.

The answer to the second question has - in my opinion - to be negative. Jonas and Schweiker, first op all, do not themselves convincingly demonstrate that a universal, realistic foundation for ethics is viable. Jonas's attempt to provide a metaphysical 
foundation for the obligation to ensure the continuing embodiment of the idea of humankind in the world has been severely criticised and rightly so. According to the criticism Jonas takes the existence of a teleological order in nature for granted in spite of prevalent views in biology that such an order does not exist. He is also guilty of the naturalistic fallacy in that he unjustifiably deduces the moral "ought" of continuing embodiment of the idea of humankind, from the mere "is" of "purposiveness" in humans as such" ${ }^{11}$. In trying to ground a "hermeneutical realism", Schweiker acknowledges that no direct access to the one true moral order is possible for human beings. We have only intermediate access to this moral order via the interpretative framework of symbols. By arguing, however, that the adequate basis for the radical interpretation that provides access to the moral order is to be found in the symbol of "God," as it has been shaped in the Christian tradition, he undermines his effort to provide a universal foundation for his imperative of responsibility. Only those who already stand within the Christian tradition would be willing to acknowledge that the Christian interpretation of the moral order is universally valid.

Secondly, one has to ask whether Jonas and Schweiker are right in asserting that prospective responsibility for the protection and enhancement of life on earth can only be exercised on the basis of a realistic foundation of a universally valid moral order. They are, of course, right in emphasising that sufficient agreement on what should be done to protect and enhance life, including future life, is needed. This does not, however, mean that sufficient moral consensus in this regard is only possible on the basis of the universal acceptance of the foundation of the moral obligations involved. The moral consensus needed is always situation specific. When an industrial company, for example, has to decide on what the company should do to protect the environment, primarily those who manage the company have to reach sufficient moral consensus. To reach moral consensus among all the industrial companies in a country, is a more difficult, but not an impossible endeavour. It is in principle even possible to achieve moral consensus internationally, although -

11 For criticism of Jonas's metaphysical foundation of the obligation to ensure the continuing embodiment of the idea of humankind see: Fischer 1998:214-215; Gerhardt 1992:105-129; Kettner 1990:73 and Müller 1988:6875. 
as the present differences regarding the Kyoto Consent clearly illustrate - in reality extremely difficult.

Typical of situation specific moral consensus, whether it is reached among only a small number of participants or a larger number of participants, is that the participants need not reach agreement on all moral issues, but only on those that are relevant in the particular situation. Apart from that, they need not agree on the ethical justification or foundation of the moral guidelines they have reached consensus on. All that is needed is that each one of the participants can find ethical justification for these moral guidelines in his or her own system of beliefs and is motivated by it to promote and apply them. No agreement on the foundation of a universally valid moral order is necessary.

\section{PROSPECTS OF A CHRISTIAN ETHICS OF RESPONSIBILITY}

If we have to conclude that the discussed two ways of conceiving a Christian ethics of responsibility - in terms of an overriding contemporary problem of responsibility for the future survival of humankind and/or in terms of responsibility as substantive moral principle - are not viable, we are faced with the serious question: does it make any sense to insist that Christian ethics should today be conceived as ethics of responsibility and to propagate such an ethics?

One has to take into account that there have also been other attempts to develop a Christian ethics of responsibility during the last few decades. Although the other proponents of a Christian ethics of responsibility mentioned in the introduction do not conceive Christian ethics as an exclusively future ethics or as an ethics based on the substantive principle of responsibility, they do insist that it makes good sense to conceive it as ethics of responsibility.

Wolfgang Huber, for example, is of the opinion that Christian ethics can be depicted as ethics of responsibility when it addresses the serious challenges with regard to responsibility that face us today with regard to collective crimes of obedience, the globalisation of modern technology and the project of modernity and, in addition to that, exhibits certain features. These features include foundation in a relational anthropology, correspondence to reality, a teleological nature and the reflexive use of principles. Johannes Fischer is wary of defining the whole of Christian ethics in terms of an ethics of 
responsibility. He sees responsibility ethics rather as one dimension of Christian ethics, namely the dimension usually depicted as duty ethics. Other dimensions include an ethics of doing (usually depicted as virtue ethics) and, what Fischer considers the most fundamental dimension of Christian ethics, the ethics of the life determined by the Spirit. For Ulrich Körtner the ethics of responsibility is a distinctively contemporary ethics in which the fundamental moral situation is not understood in terms of lawmaking and duties laid down by the lawmaker anymore, but in terms of forensic justification or responsibility. The central questions in the fundamental moral situation depicted as forensic are: who is the responsible agent, who (or what) is the instance holding the agent responsible and what is the sphere in which the agent is held responsible? Körtner is of the opinion that contemporary Christian ethics should acknowledge this shift in the understanding of the fundamental moral situation, but should provide its own, distinctive answers to the central issues involved ${ }^{12}$.

The critical discussion of these three theologians' versions of a Christian ethics of responsibility has to wait for another occasion. Only then would it be possible to make a more adequate assessment of the prospects of a Christian ethics of responsibility.

\section{Consulted literature}

Bayertz, K 1995. Eine kurze Geschichte der Herkunft der Verantwortung, in: Bayertz, K (ed.) Verantwortung: Prinzip oder Problem? Darmstadt: Wissenschaftliche Buchgesellschaft, 3-71.

Böhler, D (ed.) 1994. Ethik für die Zukunft: Im Diskurs mit Hans Jonas. München: Verlag C H Beck.

Davis, W (ed.) 2001. Taking responsibility: Comparative perspectives. Charlottesville and London: University Press of Virginia.

Fischer, J 1992. Christliche Ethik als Verantwortungsethik?, Evangelische Theologie 52 (2): 114-128.

-, 1994. Leben aus dem Geist: Zur Grundlegung christlicher Ethik. Zürich: Theologischer Verlag.

-, 1998. Handlungsfelder angewandter Ethik: Eine theologische Orientierung. Stuttgart, Berlin, Köln: Verlag W Kohlhammer.

-, 2002. Theologische Ethik: Grundwissen und Orientierung. Stuttgart: Verlag W Kohlhammer.

12 For the publications in which these theologians develop their own versions of a Christian ethics of responsibility see the Consulted literature. 
Gerhardt, V 1992. Das Prinzip der Verantwortung: Zur Grundlegung einer ökologischen Ethik: Ein Entgegnung auf Hans Jonas, in: Gerhardt, V \& Kaulbach, W (eds.). Recht und Natur: Beiträge zu Ehren von Friedrich Kaulbach. Berlin: Duncker \& Humblot, 105-129.

Hauerwas, S 1975. Character and the Christian life: A study in theological ethics. Notre Dame: University Press.

Huber, W 1990. Konflikt und Konsens: Studien zur Ethik der Verantwortung. München: Chr Kaiser Verlag.

-, 1992a. Selbstgegrenzung aus Freiheit: Über das ethische Grundproblem des technischen Zeitalters, Evangelische Theologie 52: 128-146.

-, 1992b. Strukturen verantwortlichen Lebens: Die Bedeutung Heinz Eduard Tödts für die theologische Ethik (Vortrag bei der Akademischen Gedenkfeier in Heidelberg am 6. Mai 1992).

-, 1993. Toward an ethics of responsibility, The Journal of Religion 73(4): 573-592.

-, 1994. Gewalt gegen Mensch und Natur - Die Notwendigkeit eines planetarischen Ethos, in: Rehm, J (ed.), Verantwortlich Leben in der Weltgemeinschaft: Zur Auseinandersetzung um das "Projekt Weltethos". Gütersloh: Chr Kaiser/Gütersloher Verlagshaus, 30-46.

Jonas, H 1979. Das Prinzip Verantwortung: Versuch einer Ethik für die technologische Zivilisation. Frankfurt am Main: Suhrkamp.

-, 1984. The imperative of responsibility: In search of an ethics for the technological age. Chicago \& London: The University of Chicago Press.

-, 1985. Technik, Medizin und Ethik: Praxis des Prinzips Verantwortung. Frankfurt am Main: Suhrkamp.

-, 1987. The concept of God after Auschwitz: A Jewish voice, The Journal of Religion 67(1): 1-13.

Kettner, M 1990. Verantwortung als Moralprinzip? Eine kritische Betrachtung der Verantwortungsethik von Hans Jonas, Bijdragen: Tijdschrift voor Filosofie en Teologie 51: 418-439.

Körtner, U H J 1996. Dem Risiko trotzen: Grundzüge einer zeitgemässen Verantwortungsethik, Evangelische Kommentare 29(10): 581-586.

-, 1997a. Prinzip Verantwortung? Begründungsprobleme heutiger Verantwortungsethik, Glaube und Lernen 12(2): 136-147.

-, 1997b. Solange die Erde steht: Schöpfungsglaube in der Risikogesellschaft. Hannover: Lutherisches Verlagshaus.

-, 1999. Evangelische Sozialethik: Grundlagen und Themenfelder. Göttingen: Vandenhoeck \& Ruprecht.

-, 2001. Freiheit und Verantwortung: Studien zur Grundlegung theologischer Ethik. Freiburg/Ue: Universitätsverlag; Freiburg/Br: Verlag Herder. 
Kress, H \& Müller, W E 1997. Verantwortungsethik heute: Grundlagen und Konkretionen einer Ethik der Person. Stuttgart, Berlin, Köln: Verlag W Kohlhammer.

MacIntyre, A 1981. After virtue: A study in moral theory. London: Duckworth.

McKeon, R 1957. The development and the significance of the concept of responsibility, Revue internationale de philosophie 39: 3-32.

Mitcham, C 1987. Responsibility and technology: The expanding relationship, in: Durbin, PT (ed). Technology and responsibility. Dordrecht, etc: D Reidl Publishing Company, 3-39.

Müller, W E 1988. Der Begriff der Verantwortung bei Hans Jonas. Frankfurt/M: Athenäum Verlag.

Niebuhr, H R 1978. The responsible self: An essay in Christian moral philosophy. San Francisco: Harper.

Ricoeur, P 2000. The concept of responsibility: An essay in semantic analysis, in: Ricoeur, P. The just. Chicago: University of Chicago Press, 11-35.

Römelt, J 1991. Theologie der Verantwortung: Zur theologischen Auseinandersetzung mit einem philosophischen Prinzip. Innsbruck: Resch Verlag.

-, 1996. Vom Sinn moralischer Verantwortung: Zu den Grundlagen christlicher Ethik in komplexer Gesellschaft. Regensburg: Verlag Friedrich Pustet.

Schweiker, W 1993. Radical interpretation and moral responsibility: A proposal for theological ethics, The Journal of Religion 73(40): 613-637.

-, 1995. Responsibility and Christian ethics. Cambridge: University Press.

-, 1998. Power, value and conviction: Theological ethics in the postmodern age. Cleveland and Ohio: The Pilgrim Press.

-, 1999. Verantwortungsethik in einer pluralistischen Welt: Schöpfung und die Integrität des Lebens, Evangelische Theologie 59(5): 320-335.

-, 2000. Responsibility in the world of Mammon: Theology, justice and transnational corporations, in: Stackhouse, M L \& Paris, P J (eds). God and globalization, Volume 1: Religion and the powers of the common life. Harrisburg, Pennsylvania: Trinity Press International, 105-139.

-, 2004. Theological ethics and global dynamics: In the time of many worlds. Oxford etc: Blackwell Publishing.

Tillich, P 1963. Morality and beyond. New York: Harper Torchbook.

Wieland, W 1999. Verantwortung - Prinzip der Ethik? Heidelberg: Universitätsverlag C Winter. 